\title{
What is the Effect of Thiamine Hydrochloride on Rooting of Sapindaceae Stem Cuttings?
}

\author{
Thiago de Azevedo Amorim ${ }^{1}$ (D), Natan Luiz Coelho ${ }^{1}$ (D), Genise Vieira Somner ${ }^{1}$ \\ ${ }^{1}$ Departamento de Botânica, Instituto de Ciências Biológicas e da Saúde, Universidade Federal Rural do Rio de Janeiro - \\ UFRRJ, Seropédica/RJ, Brasil
}

\begin{abstract}
Sapindaceae family presents notable richness of liana species in the Neotropics. Many of them are potentially ornamental, but still unexplored. Two Sapindaceae species were selected to test the efficiency of thiamine hydrochloride in plant propagation from stem cuttings. Thiamine hydrochloride has an unexplored potential for higher and better rooting of plant cuttings and it is a cheaper alternative to the traditional usage of phytohormones. Results showed no difference between treatment and control for all root variables evaluated in the two species studied. Seedling production from cuttings does not require application of thiamine hydrochloride in the concentration used to ensure rooting; only water irrigation is sufficient. However, further experiments involving different concentrations of thiamin hydrochloride should be conducted to detect whether different concentrations influence rooting.
\end{abstract}

Keywords: vitamin B1, vegetative propagation, seedling production. 
Sapindaceae family presents notable richness of liana species in the Neotropics (Acevedo-Rodríguez et al., 2010). Many of them are potentially ornamental, but still unexplored. To exploit their ornamental features, it is necessary to use a type of seedling propagation that guarantees higher success. Vegetative propagation using stem cuttings provides some advantages in seedling production, e.g., standardization of a phenotype of interest and faster obtainment of seedlings, considering that it is not necessary to wait for the reproductive period to collect the seeds (Fachinello et al., 2005). To this end, two species of Sapindaceae were selected to test the efficiency of thiamine hydrochloride in plant propagation from stem cuttings under different treatments: Paullinia melliifolia Juss. and Serjania cuspidata Cambess. - both frequently found in the Atlantic Forest (Somner \& Ferrucci, 2009). According to popular knowledge, the aqueous solution of thiamine hydrochloride (also known as vitamin B1) may contribute to higher and better rooting of plant cuttings; however, no scientific research has investigated this issue to date. Hence, we verified whether this substance could effectively contribute to seedling production. This study aimed to test the efficiency of thiamine hydrochloride in the rooting of two species of Sapindaceae with ornamental potential. If the effectiveness of thiamine hydrochloride is confirmed, it may be used as a cheaper alternative to the phytohormones (e.g., indole butyric acid - IBA [Atroch et al., 2000]) traditionally used in the rooting of cuttings.

We collected 60 and 50 semi-woody branches (cuttings) of P. mellifolia and S. cuspidata, respectively. The cuttings were $1-2 \mathrm{~cm}$ in diameter and $25-40 \mathrm{~cm}$ in length, with 3-4 buds. The cuttings were taken from both the apex and the middle portion of the branches. When examining the middle portion, the upper part of the cuttings was wrapped using small plastic bags to prevent loss of water trough evapotranspiration. Half of the branches of each species were used in the treatment with thiamine hydrochloride ("B1" - aqueous solution of thiamin hydrochloride at $0.4 \mathrm{mg} \cdot \mathrm{mL}^{-1}$ ) and the other half were used in the control ("Control" - water only). The B1 and Control treatments were watered on alternate days. Each cutting was placed vertically in a plastic container so that two buds remained buried in the substrate and the others were exposed. The substrate used in the containers was an equal mixture of clay and sand. The experiment was conducted for 60 days. After that, the cuttings were carefully removed from the plastic containers to avoid damaging the roots and had the following variables measured for each species: length of main roots (LMR) and dry mass of roots (DMR). Data were submitted to logarithmic transformation when the assumptions of normality and homogeneity of variances were not met. Then the $\mathrm{B} 1$ and Control treatments for each variable measured were compared using analysis of variance (ANOVA) $(\alpha \leq 0.05)$. The Chi-squared test $(\alpha \leq 0.05)$ was applied to detect possible differences in the frequency of rooting between P. melliifolia and S. cuspidata.

Results showed no difference between the B1 and Control treatments for all variables evaluated in the two species studied (Table 1). In addition, the result of the Chi-squared test showed no difference in the frequency of rooted cuttings between the species $\left(\mathrm{X}^{2}=0.124 ; \mathrm{DF}=1 ; p=0.724\right)$.

The data indicated no effect of thiamine hydrochloride on the length of main roots and dry mass of roots in both species. This suggests that, considering the concentration of thiamine hydrochloride used, there was no increase in the length or dry mass of roots in the Sapindaceae species studied. Moreover, studies involving propagation of branch cuttings of Sapindaceae species using IBA (Atroch et al., 2000) also indicated a lack of influence of IBA on the same variables assessed in this study.

Thus, our results, corroborating those reported in literature (Rodrigues \& Lucchesi, 1987; Carvalho et al., 2005; Atroch et al., 2000), reinforce that vegetative propagation in Sapindaceae can be obtained regardless of the use of growth regulators. This represents an economy in the seedling production of Sapindaceae species from branch cuttings. Furthermore, no difference was observed between the frequency of rooting cuttings and the species. This result indicates that phylogenetically related species respond similarly to the rooting of cuttings. Indeed, there is evidence that phylogenetically related species tend to respond

Table 1. Results of the ANOVA between the Control (water only) and B1 (aqueous solution of thiamin hydrochloride at $0.4 \mathrm{mg} \cdot \mathrm{mL}^{-1}$ ) treatments for the rooting of stem cuttings of Paullinia meliifolia and Serjania cuspidata. The variables analyzed for both species studied were length of main roots (LMR) and dry mass of roots (DMR).

\section{Species Variable DF $\quad$ F $\quad P(\leq 0.05)^{*}$}

\begin{tabular}{lllll} 
Paullinia meliifolia & LMR & 1 & 0.234 & 0.138 \\
Paullinia meliifolia & DMR & 1 & 0.781 & 0.385 \\
Serjania cuspidata & LMR & 1 & 0.004 & 0.948 \\
Serjania cuspidata & DMR & 1 & 0.426 & 0.524 \\
\hline
\end{tabular}

$\mathrm{DF}=$ degrees of freedom; $\mathrm{F}=$ magnitude of the effect; ${ }^{*}$ Significance level. 
similarly to the rooting of cuttings even in other taxonomic groups (Fachinello et al., 2005).

Seedling production from cuttings in Paullinia meliifolia and Serjania cuspidata does not require application of vitamin B1 in the concentration used to ensure rooting; only water irrigation is sufficient. However, further experiments involving different concentrations of thiamin hydrochloride should be conducted to detect whether different concentrations influence rooting.

\section{ACKNOWLEDGEMENTS}

The authors thank the field team from Federal Rural University of Rio de Janeiro Botanical Garden, who supported the experiments. G.V. Somner and N.L.S.C. Coelho thank the grant from ProVerde/JB/UFRRJ.

\section{SUBMISSION STATUS}

Received: 16 dec., 2015

Accepted: 24 jan., 2018

\section{CORRESPONDENCE TO}

\section{Thiago de Azevedo Amorim}

Departamento de Botânica, Instituto de Ciências Biológicas e da Saúde, Universidade Federal Rural do Rio de Janeiro - UFRRJ, Rod. BR-465, Km 07, CEP 23897-970, Seropédica, RJ, Brasil e-mail: thiagobotanica@gmail.com

\section{FINANCIAL SUPPORT}

Universidade Federal Rural do Rio de Janeiro (Grant/Award Number: 'PRO-VERDE/JB/PROPPG/ UFRRJ').

\section{REFERENCES}

Acevedo-Rodríguez P, Van Welzen PC, Adema F, Van Der Ham RWJM. Sapindaceae. In: Kubitzki K, editor. The families and genera of vascular plants. Vol. 10. Berlin: Springer; 2010. p. 357-407.

Atroch AL, Cravo MS, Santos JS. Enraizamento de estacas de clones de guaranazeiro tratados com ácido indol-3-butírico (AIB). Revista de Ciências Agrárias 2000; 47: 103-111.

Carvalho CM, Cunha RJP, Rodrigues JD. Enraizamento de estacas semilenhosas de lichieira utilizando ácido indolbutírico. Revista Brasileira de Fruticultura 2005; 27(1): 95-97. http://dx.doi.org/10.1590/S0100-29452005000100026.

Fachinello JC, Hoffmann A, Nacthigal JC. Propagação de plantas frutíferas. Brasília: Embrapa Informação Tecnológica; 2005. 221 p.

Rodrigues J, Lucchesi AA. Propagação vegetativa do guaranazeiro (Paullinia cupana (Mart.) Ducke) através de estacas induzidas (capeadas) e com ácido indolilbutúrico. Anais da Escola Superior de Agricultura Luiz de Queiroz 1987; 44(1): 1-20. http://dx.doi.org/10.1590/S007112761987000100001 .

Somner GV, Ferrucci MS. Sapindaceae. In: Stehmann JR, Forzza RC, Salino A, Sobral M, Costa DP, Kamino LHY, editors. Plantas da Floresta Atlântica. Rio de Janeiro: Jardim Botânico do Rio de Janeiro; 2009. 505 p. 